\title{
The Reform and Innovation of Ideological and Political Teaching Under the Multimedia
}

\author{
Xing Bo \\ Ideological and Political Department \\ Xi'an Peihua University \\ Xi'an, 710125, Shaanxi, China \\ e-mail: 932587282@qq.com
}

\begin{abstract}
With the continuous development of modern information technology, computer network and multimedia technology have been used more and more widely. Due to the diversity, integration, control, interactivity, and real-time characteristics of multimedia technology, the application of multimedia technology in teaching has greatly changed the traditional teaching mode of instilling knowledge to students in a single way and in a simple manner. It used its super integrated management of text, text, graphics, images, video, sound etc., making teaching intuitive, novelty, diversity and vivid characteristics, can give full play to the students' thinking ability, cognitive ability and the ability to analyze problems, greatly improve the quality of teaching. Applying multimedia technology to the ideological and political course in colleges and universities can help improve the expressiveness and appeal of teaching content, inspire students' interest in learning, increase the credibility and timeliness of teaching content, and create a multidimensional interactive ideological and political classroom model. This will enable the teaching of ideological and political courses in universities to be carried out more effectively. Therefore, we should effectively use multimedia technology to assist our teaching in ideological and political education.
\end{abstract}

Keywords-Multimedia Technology; Ideological and Political Courses in Colleges and Universities; Reform Strategy

\section{INTRODUCTION}

With the extensive application of multimedia technology in the teaching class, the ideological and political teaching in Colleges and universities has radiate new vitality and vitality, from the traditional chalk into today's participatory teaching, from the traditional single teaching mode into today's multi-dimensional interactive teaching mode, greatly improve the efficiency of ideological and political course teaching. But at the same time, it may inevitably bring about many problems, for these exist in the ideological and political class multimedia technology problems, the author puts forward some solving strategies, believe that such a tool as long as reasonable use of multimedia technology, the ideological and political education in colleges and universities can become more productive.

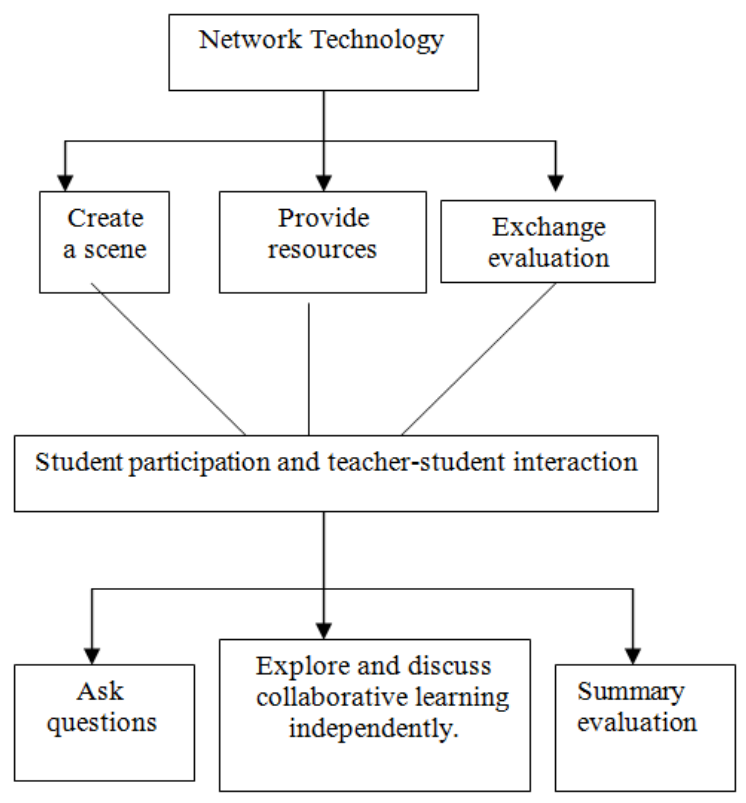

Figure 1. Network multimedia technology assisted teaching map

\section{THE ROLE OF MULTIMEDIA TECHNOLOGY IN THE TEACHING OF IDEOLOGICAL AND POLITICAL COURSES}

\section{A. Motivate students' interest in learning}

In traditional ideological education courses, teachers often use sermon teaching mode, which makes classroom teaching boring and boring, so that class becomes a teacher's "one-man show", so that students lack enthusiasm and initiative, and classroom participation is extremely low. Those students often do not know after class, so the quality and efficiency of teaching can not be achieved well.

The famous Chinese educator Confucius once said, "people who understand it are not as good as those who love it, and those who love it are not as good as those who enjoy it." The interest of learning can awaken the students' thirst for knowledge and thus improve the students' learning efficiency. Therefore, the ideological and political classroom with a relatively dull content should pay more attention to improving the students' interest and stimulating the curiosity of the students. With the use of new media technology, 
teachers can transform teaching contents into images, sounds and characters by making PPT and so on. This relatively more novel and lively teaching methods, to help students use all kinds of sense organs participate in teaching activities, passively accept to active learning, make the ideological and political education is more interesting and stimulate the students interest in learning for ideological and political education.

\section{B. Enhancing the credibility and timeliness of teaching content}

In the traditional ideological and political education class, because most of the teachers adopt the way of oral teaching, many of the views in the textbook are not so convinced by the students. But the multimedia can go beyond the limitations of time and space, make originally not intuitive knowledge of ideological and political teaching illustrated, by taking advantage of the news, documentaries, the chart data added the textbook knowledge, make both organically, let the students "seeing is believing", greatly increase the credibility of the teaching content. The ideological and political course in Colleges and universities is a curriculum which pays great attention to timeliness. However, textbook reprinting is a very time-consuming and laborious process. This leads to the fact that only by learning textbooks cannot be made of the effect of ideological and political education to keep pace with The Times .However, in the era of information technology, this situation has a new method of improvement, that is, the use of multimedia technology to innovate ideological and political education class. Because multimedia has the dynamic function of spreading the political, economic, cultural and social situations in the world, so teachers can take all kinds of current hot topics on the Internet as examples, keep pace with the social reality, and make ideological and political education advance with the times.

\section{Deepening students' understanding of ideological and political issues}

A large part of the ideological and political problems are very abstract, and it is often difficult to be understood by the students immediately through the teacher's explanation. For example, it is very difficult for students to understand the "law is the inevitable connection of things, phenomena and processes", but by listing some occasional events by pictures, it is easy to deepen students' understanding of this concept through asking and answering questions with students. In fact, many abstract problems in Ideological and political education can be solved by similar multimedia technology. Because of the intuitive features of the multimedia technology itself, it can easily establish the connection between the content and life, and create a life situation related to the teaching content. It enables students to better understand some abstract ideological and political problems, so that students can master the difficult points in the ideological and political process without difficulty, and improve the teaching quality and efficiency of teachers.

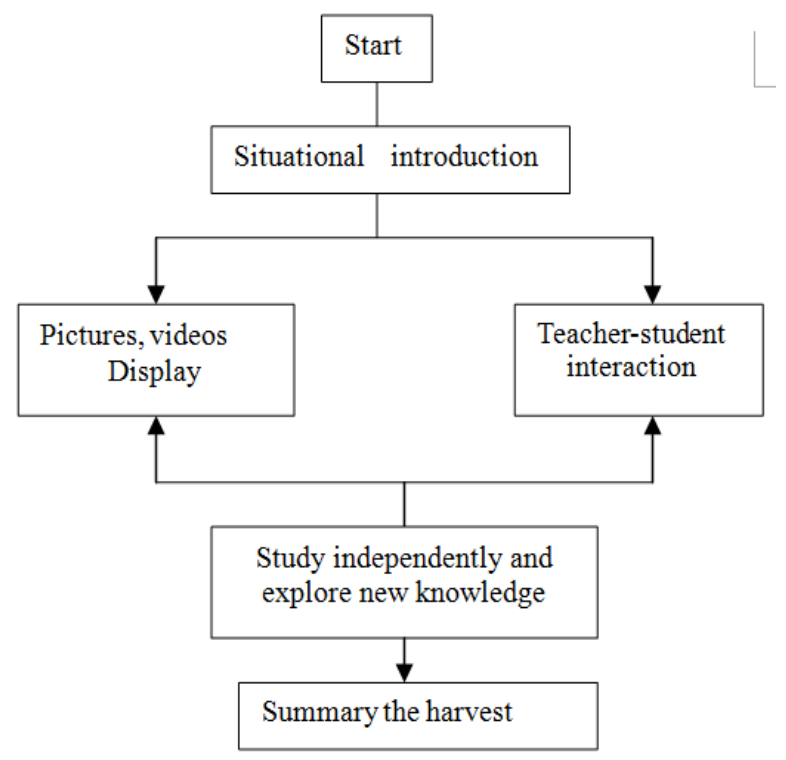

Figure 2. Multimedia technology assisting the teaching process of Ideological and Political Course

\section{Improving students' memory of teaching content}

The so-called memory "is the process of encoding, storing and extracting the input information of the outside world, which is divided into three types: instantaneous memory, short-term memory and long-term memory." In the process of ideological and political teaching, how to make the students' memory of teaching content disappear in the darkness after the "registration" in the mind, and even to the point that they have not forgotten for a long time, it has been the common pursuit of all teachers. The new media technology using the echoism tone even dynamic video several angles to promote the students' memory in teaching content, and there is conducive to students through a variety of ways to extract content. Let students "bind" what they have learned in various ways to common knowledge, increase the retention rate of students' knowledge, and improve the efficiency of education teaching.

\section{THE PROBLEMS OF THE APPLICATION OF NEW MEDIA TECHNOLOGY IN THE IDEOLOGICAL EDUCATION COURSE}

\section{A. The content of multimedia courseware is not closely related to the teaching material}

Teaching materials are a basic basis for teachers' learning, so the courseware made by teachers should be based on teaching materials. However, in the college ideological education class, some teachers pay too much attention to the novelty of courseware, so that they ignore the basic principles of teaching materials. Multimedia technology is only a supporting tool for teaching, and it is a means for teachers to better illustrate the viewpoint of teaching materials. Making courseware out of teaching materials is not only a kind of behavior that is not only to the end of the book, but also may affect the students' attention to the teaching content and hinder the students' understanding of the teaching material. In addition, in ideological education 
courses in colleges and universities, the classroom teaching is only through the courseware is very serious, teachers control the multimedia courseware to recite, rather than lead students to comprehend teaching materials, the teaching process is completely out of teaching materials. In this way, not only the teacher's subjective status in the teaching is weakened, but also the humanistic care in the ideological and political teaching material can not be read. In the long run, the harm is great.

\section{B. The concept of teachers is old and multimedia becomes formalism}

Contrary to the multimedia as the center, the ideological education in colleges and universities also exist such teachers, they ignore the role of multimedia in modern teaching. They always insist on teaching by preaching. They believe that the traditional way of teaching is simpler and easier to write and say. A survey shows that there is such a general situation in Colleges and universities that some teachers never use multimedia technology in the normal teaching process. Only when public courses are exchanged, can they open multimedia in the classroom for a long time. In this case, multimedia technology is reduced to a formalism. This situation is particularly prominent in the ideological and political teaching. In addition, the imperfect multimedia facilities in Colleges and universities are also one of the reasons for this phenomenon.

\section{Teachers become manipulators of machines, weakening students' subjectivity}

In the process of using ideological and political education with multimedia technology, because the courseware is prepared in advance, the teacher pays great attention to the whole context of the courseware, which leads to the teacher in the teaching process only pay attention to control the multimedia to complete the rigid teaching process and neglected the interaction with students. Students often focus on copying the contents of courseware onto their notebooks, and often neglect their teacher's explanation. This is not conducive to the student's thinking in the teaching process, weakening the student's dominant position, resulting in the student's rational thinking can not be good development of. Under such circumstances, multimedia is completely reduced to "instilling knowledge machine to students". It not only plays a positive role in promoting ideological and political teaching, but also hinders the emotional communication between teachers and students, making classroom teaching more dull and boring.

\section{EFFECTIVELY USING MULTIMEDIA TO REFORM IDEOLOGICAL AND POLITICAL EDUCATION}

\section{A. The multimedia courseware should be combined with the content of the textbook}

As a form of better performance of the content of teaching materials, multimedia courseware must obey the contents of the teaching material and can not be divorced from the textbook. In order to stimulate students' interest and arouse students' curiosity, some teachers cite a lot of video and audio in multimedia courseware, blindly seeking novelty, ignoring the content of textbooks, and losing the humanistic care that should be contained in teaching. Therefore, teachers must constantly explore how to organically combine multimedia courseware and teaching materials. The multimedia technology is applied to the teaching material and the living situation which is closely related to the content of the teaching material and the thinking characteristics of the students. Teachers should use the textbook as the basis, supplemented by the life situation closely related to the content of the teaching materials, and follow the thinking characteristics of the students to use the multimedia technology. Only in this way, the instrumental role of multimedia technology in university ideological and political education can be truly displayed.

\section{B. Teachers should make full use of multimedia technology to cultivate modern talents}

In the modern era of information technology development, teachers should make full use of multimedia technology to improve the quality and efficiency of ideological and political teaching in colleges and universities. The teachers of the ideological and political education curriculum should get rid of the constraints of the profession and actively learn how to use a lot of media technology in the teaching class. Schools should also pay attention to the popularization of multimedia classrooms, make effective use of resources, and train teachers in multimedia operations so that teachers can better use multimedia technology for daily teaching. In addition, teachers should also be practiced to use multimedia technology to teach and reasonably allocate time for use of courseware, so that multimedia can be effectively used without distracting students' attention.

\section{Teachers should combine multimedia technology with teaching}

"Classroom is a powerful interactive environment composed of teachers, students, and the environment. It is a systematic form of education and a unique social organization." No matter how much multimedia technology can play a role in the ideological and political class, we can never ignore the dominant position of teachers and students. After all, multimedia technology is only used as an auxiliary tool to help teaching, which is doomed it can only be a medium to connect teachers, students and teaching materials, rather than the main body of teaching activities. Especially in the teaching of ideological education, for the elaboration of viewpoints in the teaching materials, teachers cannot only use theories to convince people, and often they must also allow students to get the sublimation of their thoughts through emotional communication with students. The interaction and communication between teachers and students is an indispensable requirement for a qualified teaching activity. Teachers' language and body movements, even their eyes, play an indispensable role in multimedia technology. Therefore, we must not regard multimedia as omnipotent, and we must not let multimedia replace the status of teachers in teaching activities. 


\section{CONCLUSION}

To sum up, multimedia technology plays an active role in improving teaching activities, which is an important way to improve teaching quality and stimulate students' interest in learning. The application of multimedia technology in teaching has changed the form of traditional teaching, showing the teaching contents in the form of comprehensive multimedia information, deepening the students' understanding of knowledge, and promoting the diversified and comprehensive development of teaching methods. It fully reflects the cooperative relationship between teaching and learning and arouses students' interest in learning. However, as a means of auxiliary teaching, multimedia technology is not a master key, it has its inevitable "double edge", if it is treated reasonably and used effectively, It can greatly improve the quality and efficiency of ideological and political education, on the contrary, it will only hinder the development of ideological and political teaching activities in colleges and universities. Only by studying deeply, reasonably designing, developing and using multimedia technology, and combining it with other teaching methods, can we optimize classroom teaching and embody the real value of multimedia technology assisted teaching.

\section{REFERENCES}

[1] Wang Hongmei and Zhang Jianlong, "Research on The Combination of Multimedia Technology and Traditional Teaching Methods", Journal of Xinjiang Medical University, 2007(11).

[2] Zhang Song, "Research on Construction and Application of Ideological and Political Education Network System Based on Video on Demand in Colleges and Universities", Shenyang Normal University, 2011.

[3] Ma Dandan and Bai Jing, "Design and Implementation of the Comprehensive Information Platform for Smelting Enterprises", International Journal of Advanced Network Monitoring and Controls. Volume 2, No.4, 2017.

[4] Han Dameng and $\mathrm{Hu}$ Wanqing, "On the Problems and Countermeasures of Multimedia Teaching in Ideological and Political Courses in Universities", Professional technology, 2014(01).

[5] Zhang Haiyan, "A Survey of the Status Quo of College Multimedia Network Teaching and Strategies of Optimizing Modes", Journal of Changchun University of Science and Technology, 2011(12).

[6] Li Yihu, "Research of Integration Technology between CATIA and TOOLMANAGER Based on CAA", International Journal of Advanced Network, Monitoring, and Controls. Vol. 1, No. 1, 2016.

[7] Wei Zhang, "Fuel Cell Test System Based on AVR Single-Chip Computer", International Journal of Advanced Network, Monitoring and Controls. Volume 2, No.4, 2017.

[8] Jie Huang, "Research on Balanced Energy Consumption of Wireless Sensor Network Nodes Based on Clustering Algorithm", International Journal of Advanced Network, Monitoring and Controls. Volume 2, No.4, 2017.

[9] Jingwen Chen and Hongshe Dang, "The Design of Two Phase Chopping Regulation Voltage Soft Starter", International Journal of Advanced Network Monitoring and Controls.Volume 02, No.2, 2017 